\title{
AQUATIC/SEMI-AQUATIC MACROPHYTES USED IN HERBAL REMEDIES FROM THE WETLANDS OF WESTERN ASSAM, NORTH-EAST INDIA
}

\author{
UPEN DEKA*, TAPAN DUTTA, SANJAY TALUKDAR \\ Department of Botany, Jawaharlal Nehru College, Boko, Kamrup, Assam. Email: upen_deka@yahoo.in
}

Received: 09 February 2019, Revised and Accepted: 15 June 2019

\begin{abstract}
Objective: The aim of present investigation has been carried out for the documentation of ethnomedicinally important aquatic/semi-aquatic plants used by the rural people living in the vicinity of two major wetlands, i.e., Deepor Beel and Chandubi Beel of Western Assam, India.

Methods: Intensive field surveys were conducted with the local traditional healers to gather information on medicinal plants used by them in treatment of various ailments.

Results: Altogether 31 medicinal plant species belonging to 25 genera and 14 families have been documented from both the wetlands. Of 31 plant species, nine species were found to be used in skin disease, six in jaundice and liver problem, four species each in fever and urinary tract, two species in dysentery and snakebite, and remaining are found to be used in cough, stomach pain, wounds and cuts, neuralgia, toothache, tonsillitis, blood pressure, and smallpox.
\end{abstract}

Conclusion: Unfortunately, the population of ethnomedicinally used macrophytes Nelumbo nucifera, Euryale ferox, and Trapa natans which are rare in these two wetlands are decreasing alarmingly due to commercial exploitation, natural as well as excessive anthropogenic pressure in these two wetlands.

Keywords: Aquatic macrophytes, Anthropogenic pressure, Commercial exploitation, Medicinal plants.

(C) 2019 The Authors. Published by Innovare Academic Sciences Pvt Ltd. This is an open access article under the CC BY license (http://creativecommons. org/licenses/by/4. 0/) DOI: http://dx.doi.org/10.22159/ajpcr.2019.v12i8.32489

\section{INTRODUCTION}

Assam has the richest reservoir of plant diversity and is one of the biodiversity hot spots of the world supporting about $50 \%$ of India's biodiversity. Assam has a rich traditional knowledge of folk medicinal practices among the local traditional healer. However, rapid fragmentation of natural habitats and unrestricted exploitation coupled with limited cultivation and insufficient attempts for its replacement has decreased this knowledge day by day [1]. The Northeastern area of India is enriched with diversified plant wealth and ethnic culture. The rich floristic diversity is due to its unique geographical location and comprises forest range from tropical to alpine and has a vast reservoir of plants. Although it is rich in natural resources and ethnic culture, the ethnobotanical studies cover only $5 \%-8 \%$ of it. Area with rich flora and inherited by tribal communities provides better scope for ethnobotanical works [3-5]. Northeast India offers an immense scope for such ethnomedicinal studies since it is mostly inhabited by numerous tribes having rich folklore. Assam situated in the Northeastern region of India inhabits by a large number of tribes, particularly Mishing, Deories, Rabhas, Boro, and Kachari [6].

Assam is gifted with many extensive water bodies commonly known as "beels" which contain vitally important bioresources. Collection of several medicinal plants from the wetland is an important traditional practice by the rural people. Medicinal plants continue to provide health security to rural people throughout the world. Nowadays, it is been observed that people inhabited in remote areas mostly used plantbased medicine to cure some minor diseases. Wetlands are not only important life support system for the flora and fauna alone but also act as sources of livelihood and supply bioresource to supplement the dayto-day life of human populations living therein. Significantly, wetlands in India are facing tremendous anthropogenic pressures such as rapidly expanding human population, large-scale changes in land use and cover, and improper use of watersheds, which, in turn, greatly influence the aquatic biodiversity [2,7-10]. Anthropogenic activities, urbanization, accelerated industrialization, extensive growth of exotic aquatic weeds, encroachments, frequent, and excessive collection of aquatic resources are the major causes of the degradation of majority of the wetlands of Assam. Many works have studied on medicinal uses of the plants of Northeast India and abroad [11,12]. So far, no detail ethnomedicinal study of aquatic macrophytes of the wetlands of Kamrup district of Assam, India, has been reported by any worker. Therefore, the present investigation is an attempt to document the ethnomedicinal wetland plants and the indigenous knowledge practice by the rural people of Kamrup district of Assam.

\section{METHODS}

\section{Study site}

The study was conducted in two important wetlands of Kamrup district of Assam, namely, Deepor Beel which is a Ramsar site of Assam and Chandubi Beel, tectonic lake situated in the global position at $\mathrm{N}$ $26^{0}$ 09/26// latitude and E90 41/25// longitude and N26 53/00.1// latitude and E91 $25 / 29.5^{\circ / /}$ longitude, respectively. Both the wetlands remain covered by water along with its aquatic vegetation almost around the year.

Field trips were conducted from November 2016, to October 2017, from different communities living in the vicinities of the wetlands to collect data regarding various uses of plants and their ethnomedicinal values. Traditional medicine practitioners/healers and local villagers were also interviewed to know the medicinal importance of the plants. The collected plants were processed, dried and herbarium specimens were prepared which later on identified with the help of floras and herbaria of the Department of Botany, Gauhati University, Guwahati, Assam. The vernacular name, parts used, was recorded as per information gathered from the local traditional healers. The recorded plants are arranged in alphabetically order by their botanical names along with their families and vernacular names. 
Table 1: Aquatic macrophytes of the wetlands and their uses

\begin{tabular}{|c|c|c|c|c|c|}
\hline $\begin{array}{l}\text { Scientific name of } \\
\text { the species }\end{array}$ & $\begin{array}{l}\text { Vernacular } \\
\text { name }\end{array}$ & Family & Habitat & Parts used & Use (s) \\
\hline Acorus calamus & Boch & Araceae & $\mathrm{H}$ & Rhizome & $\begin{array}{l}\text { Rhizome powder is used in dysentery and loss of } \\
\text { appetite. Dried rhizome piece is worn along with } \\
\text { neck chain to cure whooping cough of children } \\
(\mathrm{A}, \mathrm{B}, \mathrm{R})\end{array}$ \\
\hline Alocasia indica & Mankochu & Araceae & $\mathrm{H}$ & Stem, leaf & $\begin{array}{l}\text { Leaf paste is used to wound to control bleeding } \\
\text { and stem is used as vegetable to purify blood (A, } \\
B M, B, R)\end{array}$ \\
\hline $\begin{array}{l}\text { Alternanthera } \\
\text { philoxeroides }\end{array}$ & Panikhutura & Amaranthaceae & $\mathrm{H}$ & Twig & $\begin{array}{l}\text { Young shoot and leaf juice mixed with warm } \\
\text { water to cure stomach pain }(K, R, D)\end{array}$ \\
\hline $\begin{array}{l}\text { Alternanthera } \\
\text { sessilis }\end{array}$ & Matikanduri & Amaranthaceae & $\mathrm{H}$ & Twig & Used in reducing fever $(\mathrm{M}, \mathrm{D})$ \\
\hline Centella asiatica & Bor Manimuni & Apiaceae & $\mathrm{H}$ & Stem, leaf & $\begin{array}{l}\text { Stem and leaves are used consumed as tonic } \\
\text { for improving memory and also used in skin } \\
\text { disease }(A, B M, R, B)\end{array}$ \\
\hline Centaurea diffusa & Kona simolu & Commelinaceae & $\mathrm{H}$ & Stem & $\begin{array}{l}\text { Stem juice is applied to stop bleeding of wounds } \\
\text { and cuts }(K, D, M)\end{array}$ \\
\hline Eclipta alba & Kehraj & Asteraceae & $\mathrm{H}$ & Leaf, flower & $\begin{array}{l}\text { Used in jaundice and ulcer. It is also applied on } \\
\text { wounds and skin diseases of cattle }(A, B M, K, R)\end{array}$ \\
\hline $\begin{array}{l}\text { Eichhornia } \\
\text { crassipes }\end{array}$ & Panimeteka & Pontedariaceae & $\mathrm{H}$ & Plant body & People prepare "Khar" (alkali) locally (A, BM) \\
\hline Enhydra fluctuans & Helochi & Asteraceae & $\mathrm{H}$ & Leaf, shoot & $\begin{array}{l}\text { Leaf and tender shoot are used for the treatment of } \\
\text { liver and in neuralgia and nervous diseases (A, BM, R) }\end{array}$ \\
\hline Euryale ferox & Nikori & Nymphaeaceae & $\mathrm{H}$ & Seed & $\begin{array}{l}\text { Powdered seeds are used against urinary } \\
\text { problem }(\mathrm{BM}, \mathrm{R}, \mathrm{D}, \mathrm{B})\end{array}$ \\
\hline $\begin{array}{l}\text { Hydrocotyle } \\
\text { sibthorpioides }\end{array}$ & Sarumanimuni & Apiaceae & $\mathrm{H}$ & Leaf, stem & $\begin{array}{l}\text { Leaf and stem juice are consumed for curing liver } \\
\text { problem and skin diseases }(A, D, M)\end{array}$ \\
\hline Ipomoea aquatica & Kolmou & Convolvulaceae & $\mathrm{H}$ & $\begin{array}{l}\text { Young leaf and } \\
\text { stem }\end{array}$ & $\begin{array}{l}\text { Leaf juice is used for purification of blood and } \\
\text { stem is also used in nervous diseases } \\
(A, B M, M, D)\end{array}$ \\
\hline $\begin{array}{l}\text { Ludwigia } \\
\text { adscendens }\end{array}$ & Panikhutura & Onagraceae & $\mathrm{H}$ & Leaf & $\begin{array}{l}\text { Leaf juice is used in jaundice and skin } \\
\text { disease (BM) }\end{array}$ \\
\hline $\begin{array}{l}\text { Marsilea } \\
\text { quadrifolia }\end{array}$ & Panitengesi & Marsileaceae & $\mathrm{H}$ & Tender shoot & Tender shoots are used as vegetable (K, D, M) \\
\hline Monochoria hastata & Kar meteka & Pontederiaceae & $\mathrm{H}$ & $\begin{array}{l}\text { Tender leaf, } \\
\text { flower }\end{array}$ & $\begin{array}{l}\text { Tender leaves and flowers are used as } \\
\text { vegetable. }(A, R, B)\end{array}$ \\
\hline Nelumbo nucifera & Podum & Nymphaeaceae & $\mathrm{H}$ & $\begin{array}{l}\text { Rhizome, leaf } \\
\text { petiole, fruiting } \\
\text { torus }\end{array}$ & $\begin{array}{l}\text { Rhizome, leaf petioles, and fruiting torus are } \\
\text { sold as vegetables and the flowers are used for } \\
\text { sacred offering in Hindu rituals. Roots are used in } \\
\text { smallpox and dysentery. (BM, A) }\end{array}$ \\
\hline Nymphaea alba & Boga vet & Nymphaeaceae & $\mathrm{H}$ & Stem & $\begin{array}{l}\text { Stem is used as vegetable to cure dysentery. (BM, } \\
\text { A, B) }\end{array}$ \\
\hline Nymphaea nouchali & Bhet & Nymphaeaceae & $\mathrm{H}$ & $\begin{array}{l}\text { Petiole and } \\
\text { rhizome }\end{array}$ & $\begin{array}{l}\text { Petioles and rhizomes are used as supplementary } \\
\text { vegetable. It is also used to cure disease related to } \\
\text { urinary tract. (BM, B, R) }\end{array}$ \\
\hline Nannodiplax rubra & Ronga-bhet & Nymphaeaceae & $\mathrm{H}$ & Fruit, flower & $\begin{array}{l}\text { Fruits are consumed as raw and flowers are used } \\
\text { for sacred offering in Hindu rituals. (A) }\end{array}$ \\
\hline Nymphoides indica & Buta bhet & Nymphaeaceae & $\mathrm{H}$ & Petiole, rhizome & It is also used for reducing fever. (BM, K, R) \\
\hline $\begin{array}{l}\text { Nymphoides } \\
\text { hydrophylla }\end{array}$ & Pan chuli & Nymphaeaceae & $\mathrm{H}$ & Leaf & $\begin{array}{l}\text { Leaf juice is used in jaundice and skin } \\
\text { infection. (BM, B, R) }\end{array}$ \\
\hline Ottelia alismoides & Panikola & Hydrocharitaceae & $\mathrm{H}$ & Leaf & $\begin{array}{l}\text { Leaves are used as poultices on arms and legs to } \\
\text { control fever. (R, M) }\end{array}$ \\
\hline Pistia stratiotes & Borpuni & Araceae & $\mathrm{H}$ & Whole plant & It is also used in skin disease, ulcer, and piles. $(\mathrm{K}, \mathrm{B}, \mathrm{R})$ \\
\hline $\begin{array}{l}\text { Polygonum } \\
\text { hydropiper }\end{array}$ & Bihlongoni & Polygonaceae & Sh & Leaf & $\begin{array}{l}\text { Leaf juice is used in skin disease and uterine } \\
\text { disorder. }(A, B M, R)\end{array}$ \\
\hline Rumex nepalensis & Bon paleng & Polygonaceae & $\mathrm{H}$ & Leaf & Leaf juice is applied in burning. (K, D, M) \\
\hline $\begin{array}{l}\text { Sagittaria } \\
\text { sagittifolia }\end{array}$ & Pani-kochu & Alismaceae & $\mathrm{H}$ & Leaf & $\begin{array}{l}\text { Leaf is antiseptic and is known to be used in } \\
\text { snake and insect bite. (K, R, D) }\end{array}$ \\
\hline $\begin{array}{l}\text { Spilanthes } \\
\text { paniculata }\end{array}$ & Suhani & Asteraceae & $\mathrm{H}$ & Flower & $\begin{array}{l}\text { Flowers are chewed to get relief from tonsillitis } \\
\text { and toothache. }(A, B M, R, B, M)\end{array}$ \\
\hline $\begin{array}{l}\text { Trapa natans var. } \\
\text { bispinosa }\end{array}$ & Singori & Trapaceae & $\mathrm{H}$ & Fruit & $\begin{array}{l}\text { Fruits are eaten raw and used for curing problem } \\
\text { of urinary trouble. }(A, B M, D, R)\end{array}$ \\
\hline $\begin{array}{l}\text { Xanthium } \\
\text { strumarium }\end{array}$ & Agora & Asteraceae & $\mathrm{H}$ & Seeds, fruits & $\begin{array}{l}\text { Used in chronic malaria and urinary troubles. } \\
\text { Fruits are also used to cure smallpox. (BM, R, K) }\end{array}$ \\
\hline
\end{tabular}

$\mathrm{H}=$ Herb, Us= Under shrub, $\mathrm{Sh}=$ Shrub, $\mathrm{A}=$ Assamese, $\mathrm{BM}=$ Bengali muslim, $\mathrm{K}=$ Kabri, $\mathrm{B}=\mathrm{Bodo}, \mathrm{R}=\mathrm{Rabha}, \mathrm{D}=$ Deori , M=Mishing 
Table 2: Correlation study of uses of plant species and diseases

\begin{tabular}{|c|c|c|c|c|c|c|}
\hline Communities & Skin disease & Jaundice and liver problem & Fever & Urinary disease & Dsentry & Snake bite \\
\hline Assamese & $0.633^{* *}$ & $0.578^{*}$ & $0.438 *$ & -0.278 & $0.642 * *$ & -0.235 \\
\hline Bengali Muslim & $0.762^{* *}$ & 0.442 & 0.558 & -0.275 & $0.754 * *$ & -0.357 \\
\hline Karbi & 0.273 & -0.342 & -0.479 & 0.342 & -0.668 & $0.528^{* *}$ \\
\hline Bodo & -0.254 & -0.459 & 0.327 & -0.449 & $0.526^{* *}$ & $0.734^{* *}$ \\
\hline Rabha & $0.548^{* *}$ & $0.674^{* *}$ & 0.552 & $0.632^{* *}$ & -0.137 & 0.239 \\
\hline Deori & -0.486 & -0.129 & -0.337 & $0.534^{* *}$ & 0.478 & 0.352 \\
\hline Mishing & -0.192 & 0.348 & -0.576 & 0.476 & $0.593^{* *}$ & 0.367 \\
\hline
\end{tabular}

${ }^{* *}$ Correlation is significant at the 0.01 level (two tailed). ${ }^{*}$ Correlation is significant at the 0.05 level (two tailed)

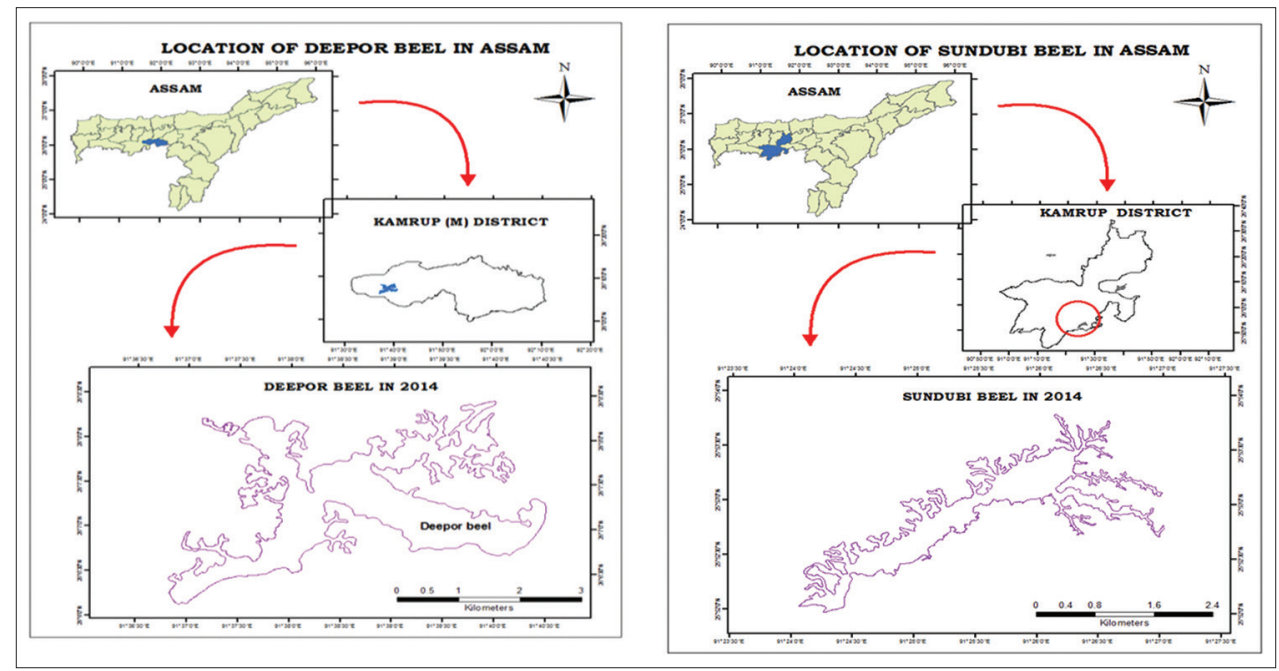

Fig. 1: Location maps of the study area

\section{RESULTS AND DISCUSSION}

The present study involves a total number of 31 species of aquatic/ semi-aquatic plants under 14 families and 25 genera, which are used as herbal remedies by the different communities living in the vicinities of the two wetlands of the district (Table 1). Of 31 medicinal plant species documented, nine species were found to be used in skin disease, six in jaundice and liver problem, four species each in fever and urinary tract, two species in dysentery and snakebite, and remaining are found to be used in cough, stomach pain, wounds and cuts, neuralgia, toothache, tonsillitis, blood pressure, and smallpox (Fig. 2). It has been observed that most of the inhabitants around the wetlands of the study sites are economically very poor and the communities belong to Assamese and Bengali Muslim, and the tribal communities are Karbi, Bodo, Rabha, Deori, and Mishing.

Although fishing is the primary livelihood of the poor people living in the fringe areas of these two wetlands, many aquatic plant species are collected regularly for their day-to-day use and also as a source of income. People of the neighboring areas collect resources from the wetlands for fodder, vegetables, medicines, biofertilizers, and religious functions. Medicinal plants are mostly used by different communities for curing minor diseases in their day-to-day lives. Enhydra fluctuans and Ipomoea aquatica are used to cure nervous diseases and Trapa natans for urinary trouble. The rhizome of Acorus calamus is used in dysentery and loss of appetite and cough. I. aquatica locally known as kolmou is a common vegetable sold in the market of Assam. The stem of Alocassia and torus of Nelumbo nucifera are also delicacies and expensive traditional food items of Assam. During investigation, it has been observed that a single plant can be used for more than two different purposes. The population of $A$. calamus Linn. has been declining in the wild habitat, but due to its high demand, few people living in the vicinity of the wetlands now have been cultivating the species in their home gardens. I. aquatica are used as vegetable as well as for herbal medicine. Likewise, N. nucifera and Nymphaea spp., besides using as medicinal

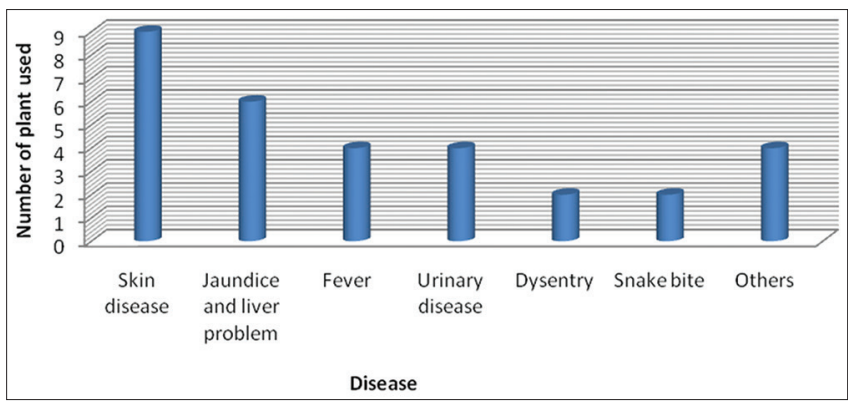

Fig. 2: Plants used in different diseases

plants, are also used as vegetable and religious functions (Table 1). Euryale ferox and T. natans are closely associated with the legends of Deepor Beel, but its population has been declining in such a way that it will soon disappear from the beel if proper conservation measures are not taken up in time. Most of the aquatic plants are grown wild, and hence, people freely collect them for their livelihood and source of income.

The present study also reveals that approximate 800 schedule caste population depends on Deepor Beel for fishing and is the only source of livelihood. However, significantly, the diversity of fishes decreases alarmingly in the wetland due to contamination of polluted water that make wetland water unhealthy for fish survival which affected badly not only livelihood of the wetland depending communities but also the whole wetland ecosystem as well. People who earlier collect fishes from the wetland now began to collect economically and medicinally important plant species, i.e., E. ferox, T. Natans, and N. nucifera to sell in the nearby markets. Hence, the population of these macrophytes is gradually decreasing over the past few decades. However, due to continuous siltation and rapid eutrophication rate, the southern 
side of Chandubi Beel is becoming very shallow and some parts have already been converted into terrestrial agricultural land. As a result, ethnomedicinally important aquatic macrophytes found in the ecotone region have already been disappeared from those areas of the wetland.

Study reveals that Bengali Muslim people showed more positive correlation of the uses of plant species for curing diseases among all the studied communities. Interestingly, the tribal communities showed positive correlation of uses of plant species against snakebite (Table 2).

Chorei tribe of Southern Assam uses leaf extract of Eclipta prostate in treatment of Jaundice [13]. Similar finding has also been reported during the present study. It has been found that the use of medicinal plants for treatment of jaundice by different people of Assam is not similar. Leaf juice and bark of Media azadirachta are used by mishing tribe of Lakhimpur district of Assam to cure jaundice [14]. Nath people of Marigaon district of Assam use leave juice and root of Eclipta prostate to cure jaundice while Bodo, Rabha, Koch Rajbanshi and Santal of North Kamrup of Assam use whole plant juice of Nymphoides indica [15]. Rhizome of Acorus calamus is used for treatment of indigestion, diarrhea, tuberclousis, cough and cold [16] and during present study also similar findings has also been recorded.

From the above study it can be state that the traditional medicine for cure a particular kind of disease of various communities of Assam is different. There is a variation in the medicinal plants as well as the parts used by the different communities of the state. It is mainly due to the availability of local resources and traditional knowledge of the community.

\section{CONCLUSION}

These two wetlands are the major source for livelihood support of the fisherman community living in its vicinity. However, gradually such valuable wetlands, which possess several medicinally important plants, are degrading due to natural as well as several anthropogenic activities including eutrophication, encroachment for construction of houses, industry as well as agricultural purposes, excessive collection of resources for commercial purposes, and partial blockage of both inlet and outlet channel of the wetland results strictly stagnant water which supports the luxuriant growth of invasive aquatic macrophytes, i.e., Eichhornia crassipes in Deepor Beel particularly. This aggressive growth of water hyacinth is also another major cause of decreasing the population of economically and ethnomedicinally important species, N. nucifera, T. Natans, and E. ferox in the wetland. Therefore, proper conservation measures of these macrophytes and immediate attention of their ethnomedicinal uses should be taken at the earliest to protect these important wetlands from degradation and also for the benefit of local people living in its vicinities.

\section{ACKNOWLEDGMENT}

Authors are gratefully acknowledged to Advanced Level Institutional Biotech Hub, J. N. College, Boko, for providing laboratory facility. We also like to convey our heartiest and sincere thanks to the respective traditional healers and the local villagers for their help and support during the survey of this present research works.

\section{AUTHORS' CONTRIBUTIONS}

All the authors significantly contributed equally.

\section{CONFLICTS OF INTEREST}

The authors have no conflicts of interest.

\section{REFERENCES}

1. Das AJ, Kumar R, Mohammad A, Singh RV, Kumar M, Khan M, et al. Ethnomedicinal study of threatended plants of Sonitpur district in Assam, North East India. Int Res J Pharm 2013;4:146-9.

2. John J, Francis MS. Wetland algal resources of Western Ghats (Idukki district region), Kerala, India. J Basic Appl Biol 2010;4:34-9.

3. Jain SK. Ethnobotany: Its scope and study. Indian Mus Bull 1967;2:39-43

4. Jain SK. Ethnobotany. Interdiscip Sci Rev 1986;11:285-92.

5. Jain SK. Manual of Ethnobotany. Jodhpur: Scientific Publication; 1987.

6. Lagachu J, Kalita JC. A study on ethnomedicinal uses of plants in Dhemaji district of Assam with special reference to reproductive health. Int Res J Pharm 2013;4:261-3.

7. Kumar P, Gupta SK. Diversity and abundance of wetland birds around Kurukshetra, India. Our Nat 2009;7:212-7.

8. Prasad SN, Ramachandra TV, Ahalya N, Sengupta T, Kumar A, Twiwari AK, et al. Conservation of wetlands of India a review. Trop Ecol 2002;43:173-86.

9. Ramachandra TV. Wetlands: Need for appropriate strategies for conservation and sustainable management. J Basic Appl Biol 2010;4:1-17.

10. Singh AK, Panday RK, Singh S. Understanding wetlands. Everymans Sci 2006;12:116-9.

11. Swargiary A, Nath P, Basumatary B, Brahma D. Phytochemical, antioxidant and trace element analysis of anthelmintia plants of North East India. Int J Pharm Pharm Sci 2017;9:228-32.

12. Thakur RS, Ahirwar B. Ethnopharmacological evaluation of medicinal plants for cytotoxicity against various cancer cell lines. Int J Pharm Pharm Sci 2017;9:198-202

13. Choudhury S, Sharma P, Choudhuri MD, Sharma GD. Ethnomedicinal plants used by chorei tribes of Southern Assam, North East India. Asian Pac J Trop Dis 2012;4:141-7

14. Medhi BK. Ethnomedicine: A study among the mishings in a rural context. Bull Dep Anthropol Gauhati Univ 1995;9:61-8.

15. Sikdar M, Dutta U. Traditional phytotherapy among the Nath people of Assam. Ethnomedicine 2008;2:39-45.

16. Das A, Kumar R, Mohammad A, Singh RD, Kumar M, Khan MA, et al. Ethno medicinal study of threatened plants of Sonitpur district in Assam, North East India. Int Res J Pharm 2013;4:146-9. 